\title{
DA GASTRONOMIA FRANCESA À GASTRONOMIA GLOBAL: hibridismos e identidades inventadas ${ }^{1}$
}

\author{
Maria Lúcia Bueno*
}

\begin{abstract}
O objetivo desta reflexão é compreender a transformação da dinâmica do processo de mundialização na globalização, tendo como tema a gastronomia, pensada como campo cultural (Bourdieu), e tendo como recortes os chefs de cozinha, os restaurantes e os guias gastronômicos, analisados numa perspectiva sócio -histórica. Considerando o equilíbrio estabelecido entre a penetração da cultura gastronômica em âmbitos mais distantes uns dos outros, além de diversos entre si, a proposta do artigo é discutir como a consolidação de um mercado global de gastronomia está na contrapartida de exercícios contínuos de afirmação de localidades e identidades particulares.

Palavras-chave: Campo gastronômico. Globalização. Chefs-restaurantes. Gastronomia francesa. Gastronomia brasileira. Identidades inventadas.
\end{abstract}

A gastronomia é uma estetização da maneira de comer, que envolve desde a produção da comida até o ritual da refeição (Poulain, 2004; Rambourg, 2010). Até alguns anos atrás, era um assunto de interesse restrito, confinado à órbita das elites econômicas que podiam frequentar os restaurantes dos chefs franceses, e de um pequeno grupo de gourmets e especialistas, uma vez que só existia cultura gastronômica na França (Ferguson, 2004). Os poucos espaços gastronômicos que despontavam fora do país eram conduzidos por chefs franceses, ou então formados nas instituições francesas, seguindo rigorosamente seus preceitos.

Mas, a partir de 1970 e 1980, há uma mudança nesse panorama, com o aparecimento de uma nova geração de chefs que, atuando a partir de outros polos - da América Latina, dos Estados Unidos, da África e da Ásia - con-

\footnotetext{
* Universidade Federal de Juiz de Fora (UFJF), Minas Gerais. Programa de Pós-Graduação em Ciências Sociais e do Programa de Pós-Graduação em Artes, Cultura e Linguagens. Campus Universitario. Cep: 36036330. Martelis - Juiz de Fora - Minas Gerais - Brasil. marialucia.bueno@gmail.com ${ }^{1}$ A presente reflexão é parte de uma pesquisa desenvolvida entre Paris e Nova York, com apoio de uma bolsa de pós-doutorado senior concedida pela CAPES.
}

tribuiu para reinventar a cultura gastronômica, ampliando consideravelmente sua geografia. $\mathrm{O}$ impacto dessas mudanças, amplificado pelos meios de comunicação, converteu o setor em centro de debates e discussões em vários âmbitos e segmentos sociais. Esse protagonismo transparece na expansão das publicações na área (livros, revistas especializadas e cadernos de jornais) e na crescente visibilidade adquirida pelo setor na mídia (programas de televisão, documentários, filmes, difusões radiofônicas, entre outros), responsável pela transformação dos chefs em verdadeiras celebridades.

Esse fenômeno está ligado a vários fatores relativos à globalização (Appadurai, 1996; Crane, 2012; Ortiz, 1994), entre os quais destacamos a ampliação da sociedade de consumo, com aprofundamento das práticas e estilos de vida associadas à estetização do cotidiano (Featherstone, 1995), e as revoluções parciais ocorridas no interior do campo (Bourdieu, 1996) da gastronomia (Rao; Monin; Durand, 2003, 2005). Nessa nova configuração, o mundo da gastronomia, até então investigado principalmente por suas conexões com a cultura de elite e a distinção social, vem despontando 
também como um universo privilegiado para a compreensão de questões como a construção das identidades, das hegemonias culturais e diversidades na sociedade contemporânea.

O presente artigo reflete sobre essas questões, abordando as mudanças no campo gastronômico numa perspectiva sócio-histórica, tendo como principal recorte a gastronomia brasileira. Em texto anterior (Bueno, 2013), analisamos sua emergência do ponto de vista interno, da conjuntura política e sociocultural no país. Nesta reflexão, vamos trabalhar o problema da perspectiva externa, das relações que estabelece com as dinâmicas do campo gastronômico, considerando particularmente sua evolução de um espaço nacional e internacional para um espaço global.

\section{GASTRONOMIA BRASILEIRA: um produto da globalização?}

A gastronomia é um fato recente no Brasil. Pode ser identificada a partir de meados dos anos 1990, quando despontou a primeira geração de chefs brasileiros, mas se consolidou e adquiriu visibilidade apenas no início do segundo milênio. Até então, o que havia entre nós eram cozinhas regionais, de tradição popular, valorizadas como patrimônio imaterial, que foram objeto de estudo de folcloristas, como Luís da Câmara Cascudo (1967). Essas cozinhas, e muitos dos seus ingredientes, peri maneceram ativos no ambiente doméstico em algumas regiões rurais do país. Nos principais centros urbanos, sobreviveram no universo - privado e nos restaurantes típicos, reduzidas a ¿ alguns clichês da nossa identidade alimentar, j como a feijoada, o virado à paulista ou o tutu à mineira e a moqueca baiana.

Desde o início do século XIX, a tradição culinária dominante na corte brasileira, nos salões oficiais e nos privados, era a da alta cozinha francesa, difundida a partir de livros e compêndios especializados (Couto, 2007). Mais tarde, em meados do século XX, a maior parte dos restaurantes sofisticados, nos principais centros urbanos do país, adotava um modelo conhecido como cozinha internacional, que vinha a ser uma versão padronizada de alguns estereótipos da gastronomia francesa, difundida a partir dos Estados Unidos (em cadeias de hotéis, como a do Hilton). No decorrer dos anos 1960, quando o hábito de jantar fora se fortaleceu, surgiram redes de restaurantes com uma forte presença do segmento imigrante. Em São Paulo, predominavam os italianos (Collaço, 2009; Masano, 2011) e, no Rio de Janeiro, os portugueses (Bueno, 2013).

\section{O QUE É GASTRONOMIA? COZI- NHA CULTA, COZINHA POPULAR E GASTRONOMIA}

A alta cozinha, ou cozinha culta, consolidou-se na sociedade de corte francesa como uma das expressões do processo civilizador. Diferentemente das cozinhas populares, de tradição oral, objetos de inúmeros desvios e versões, as cozinhas cultas foram codificadas em obras escritas, com registros minuciosos das receitas.

Para o sociólogo francês Jean-Pierre Poulain (2004), a partir do século XVII, houve a difusão internacional da cozinha francesa, que foi se tornando mais complexa, configurando-se como disciplina e como sistema. Esse movimento foi seguido por uma mudança na organização das publicações especializadas: "passa-se do livro 'compêndio', simples lista de pratos, para uma ferramenta que permite fazer funcionar um código e quase já uma verdadeira linguagem" (Poulain, 2004, p. 226). Opera simultaneamente como um livro de vocabulário e um manual de gramática.

Expõe um código complexo que distingue os produtos de base, as técnicas de cozimento, as técnicas de combinações, os acompanhamentos de legumes, os molhos; outros tantos elementos que se combinam entre si segundo regras de uma extrema precisão, para dar nascimento a novos pratos: ou seja, pratos 
não descritos no livro mas contidos no código. [...] o cozinheiro não cria um prato, mas fala uma língua (Poulain, 2004, p. 226).

A gastronomia foi um processo posterior, que surgiu após a Revolução Francesa, com a difusão e a expansão da alta culinária a partir dos cafés e restaurantes, novas instituições urbanas parisienses que se multiplicaram na primeira metade do século XIX ${ }^{2}$ (Drouard, 2007). Com a dissolução da corte e dos salões da aristocracia, os cozinheiros que não acompanharam seus patrões no exílio migraram para os estabelecimentos comerciais. Foi nesse contexto de transformações políticas, sociais e ideológicas, assinalado pelo crescimento do público consumidor da cozinha culta, que a gastronomia se desenvolveu como uma modalidade de pensamento científico aplicado à cultura alimentar, criando um conjunto de regras que passou a operar sobre as maneiras e os hábitos dos consumidores. O termo gastronomia, ${ }^{3}$ designando uma cozinha criativa, data de 1801, e a palavra gastrônomo, para nomear o status do consumidor dessa nova cozinha fina e elaborada, aparece em 1803 (Drouard, 2007; Ferguson, 1998; Poulain, 2004). Contrapondo-se aos excessos e exageros do Antigo Regime, a gastronomia desponta como uma nova norma de civilidade, um modelo de disciplina, controle e moderação.

Passou-se a distinguir a gastronomia da voracidade e da glutoneria: ela foi vista como uma tendência que se podia confessar, como uma qualidade social, agradável para o anfitrião, proveitosa para o conviva, útil para a ciência, e os gastrônomos foram postos ao lado de todos os outros aficionados que também têm uma predileção comum (Brillat-Savarin, 2005, p. 277).

A gastronomia, portanto, não pode ser reduzida à cozinha e à comida. Ela mobiliza todo um repertório de maneiras de se relacionar com elas que se materializa na cerimonia da refei-

2 Até 1789 , existiam menos de cem restaurantes funcionando em Paris. Em 1804, havia entre 500 e 600 estabelecimentos. Em 1825, cerca de mil e, em 1834, em torno de 2.000 .

${ }^{3}$ Gastro (estômago) e nomia (regras). ção, ritual que só pode ser compreendido em sua ligação com a dinâmica dos estilos de vida. A gastronomia envolve o aparato material das refeições - a comida, os vinhos, assim como a decoração dos pratos, da mesa e da sala de refeições. Na sociedade de corte, a decoração e a cenografia do jantar chegavam a ser mais importantes do que a comida (Rambourg, 2010). Além disso, as maneiras de comer, de servir, a organização da sequência dos pratos no menu e o tempo de duração das refeições também são aspectos fundamentais na construção da cultura gastronômica. Por essas razões, a compreensão do papel do chef, figura responsável pela coordenação de todas essas operações, não pode se ater apenas aos aspectos ligados à culinária. Mas, nesta abordagem sobre as transformações do campo gastronômico, vamos priorizar as questões relativas à cultura culinária.

\section{GASTRONOMIA COMO CAMPO CULTURAL FRANCÊS}

Os caminhos da alta culinária, antes determinados pela autoridade do rei e a etiqueta da corte, agora em outro contexto social, passaram a ser definidos a partir de uma nova configuração, a gastronomia, que tinha como principais agentes os chefs de cozinha e os críticos e, como instâncias de difusão e consagração, as publicações. Para Priscilla Ferguson (1998), a gastronomia se constituiu, nessa ocasião, como um campo cultural autônomo, conforme a conceituação de Pierre Bourdieu (1996), operando com a independência relativa dos fenômenos externos, conduzida por uma lógica própria, fundada em regras e procedimentos próprios. Essa autonomia da alta culinária pressupunha também a independência dos preceitos médicos e religiosos que legislavam tradicionalmente sobre as práticas alimentares.

A fundação desse campo foi liderada por uma nova categoria de autores, responsáveis pelo aparecimento de uma literatura gastronômica (jornalismo, livros de cozinha, ensaios 
protossociológicos e de filosofia política, e trabalhos literários), que promoveu uma expansão e uma nacionalização do discurso culinário. Esse discurso garantiu a autonomia do campo, determinando seu funcionamento. O fortalecimento do mercado editorial, possibilitando interações entre o campo literário e o campo gastronômico, contribuiu para a construção de uma aura de prestígio em torno do setor (Ferguson, 1998). Mediante essa nova configuração, acentuaram-se as clivagens entre os universos da cozinha culta e das cozinhas populares.

Chefs como Antonin Caramê (17831833) e Auguste Escoffier (1846-1935), que, em momentos diferentes, reformularam e modernizaram os parâmetros da culinária do antigo regime, tiveram o alcance de suas ações amplificado por seus escritos, traduzidos em vários idiomas (Drouard, 2007; Poulain; Neirinck, 2004; Rambourg, 2010). Porém o sucesso definitivo do empreendimento deveu-se à colaboração dos novos intelectuais do campo, os críticos especializados, como Brillat-Savarin (1755-1826) e Grimod de la Reynière (1758 -1837), que, por meio de suas publicações e da criação de mecanismos de avaliação, como os júris de degustação e de legitimação, foram estabelecendo uma mediação entre a produção dos chefs e o seu público consumidor (Ferguson, 2004). Obras pioneiras como L'Almanach de Gourmand (1802), de Reynière, e La Physiologie du goût (1826), de Brillat-Savarin (Brillat-Savarin, 2005), foram fundamentais para a construção da cultura gastronômica.

\section{COZINHA INTERNACIONAL FRANCESA}

A gastronomia se constituiu e se consolidou como campo cultural, num contexto de mundialização, quando o desenvolvimento de novas tecnologias ligadas à produção agrícola e ao sistema de transportes gerou um movimento de desterritorialização de produtos e tradições de diferentes regiões do planeta (Poulain, 2004; Rambourg, 2010). Nos primeiros 150 anos, do início do século XIX a meados do século XX, evoluiu em um processo de mundialização internacionalizado, tendo como centro a França. Respaldado por uma sólida tradição culinária, beneficiado por mecanismos institucionais e intelectuais próprios, o campo francês inventou a moderna gastronomia por sua capacidade, naquele momento histórico, de atuar como mediador dos trânsitos mundializados, operando em dois sentidos: 1) incorporando as influências estrangeiras no interior da alta cozinha e 2) difundindo, a partir de Paris, uma gastronomia mundializada e cosmopolita, transvestida em produto nacional, que foi rapidamente assimilada nos principais centros metropolitanos.

O projeto de Caramê (Kelly, 2005) foi a promoção da cozinha francesa como instituição moderna, que não operava isolada, mas que assimilava e incorporava elementos estrangeiros. Grimod de la Reynière (1806) mencionava um processo de afrancesamento, mediante o qual a alta cozinha francesa se apropriava de ingredientes e comidas exóticas, aperfeiçoando-os.

Vinte anos depois, Brillat-Savarin registrava uma descrição da gastronomia num restaurante parisiense, destacando a riqueza da diversidade de escolhas.

[...] o feliz gastrônomo podia regar sua refeição com pelo menos trinta espécies de vinho a escolher, desde Borgonha até o vinho de Tokaj ou da Cidade do Cabo; e vinte ou trinta tipos de licor, sem contar o café e bebidas como o ponche, o negus e outras semelhantes. Entre esses diversos ingredientes da refeição de um aficionado, os principais vinham da França, como a carne de açougue, a caça e as frutas; outros eram de origem inglesa, como o beef-steak, o welch-rabbit, o ponche etc.; outros vinham da Alemanha, como o sauer-kraut, a carne de Hamburgo, os filés da Floresta Negra; outros da Espanha, como a olla podrida, os garbanzos, as uvas secas de Málaga, os pernis na pimenta de Xerica e os vinhos licorosos; outros da Itália, como o macarrão de Bolonha, a polenta, os sorvetes e os licores; outros da Rússia, como as carnes secas, as enguias defumadas, o caviar; outros da Holanda, como a moreia, os queijos, os arenques na salmoura, o curaçau, o licor de anis; outros da Ásia, como o arroz da Índia, o sagu, o curry, o molho de 
soja, o vinho de Xiraz, o café; outros da África, como o vinho do Cabo; outros enfim da América, como a batata, a batata-doce, o ananás, o chocolate, a baunilha, o açúcar etc. O que é uma prova suficiente da proposição que emitimos mais acima, a saber: que uma refeição feita em Paris é uma viagem cosmopolita em que cada parte do mundo está representada por seus produtos (Brillat-Savarin, 2005, p. 182).

\section{LITERATURA, GASTRONOMIA E BOÊMIA}

No século XIX, os chefs já eram identificados a partir do mundo dos restaurantes, o que possibilitou-lhes uma nova posição de independência social e financeira. Mas, como a sociabilidade da aristocracia e da alta burguesia ainda se mantinha restrita aos espaços privados, sendo que as mulheres de famílias burguesas e aristocratas não frequentavam restaurantes (James, 2008), os chefs circulavam igualmente pelas cozinhas dos palácios públicos e particulares, onde atuavam esporadicamente como profissionais autônomos (Drouard, 2010).

A boêmia, que emerge como uma nova esfera cultural no século XIX, reunindo intelectuais e artistas de vanguarda que difundiam um novo estilo de vida (Bueno, 2001; Seigel, 1992), foi o principal público dos restaurantes no período. Esse fato propiciou uma estreita ligação entre a vida literária e o mundo dos restaurantes, transformando a gastronomia em tema recorrente nas obras de autores de prestígio como Balzac e Alexandre Dumas (Ferguson, 2004). Entre a cidade e a literatura, foi-se moldando um novo estilo de vida que a projeção dos literatos consagrou. No final do século, os espaços frequentados pelos poetas e artistas eram os mais procurados pelos turistas internacionais (Seigel, 1992). Nas primeiras décadas do século XX, os restaurantes reputados como espaços gastronômicos se transformaram em redutos de luxo e prestígio, frequentados por homens e mulheres do mundo elegante internacional (Huetz de Lemps; Pitte,
1990; Spang, 2003).

Aos poucos, a gastronomia francesa foi se delineando como uma tradição inventada (Hobsbawn, 1984), tendo o cosmopolitismo como um dos seus principais atributos (Ferguson, 2004). Essa diversidade ganha um novo significado e uma unidade no interior do sistema da alta cozinha francesa que, sobrepondo-se às tradições particulares, foi moldando, domesticando, civilizando, reconfigurando as influências estrangeiras numa nova tradição que se internacionalizou como gastronomia francesa.

Foi a partir dos textos que essa construção gastronômica se difundiu para os consumidores gastronômicos, os leitores. Para Priscilla Ferguson $(1998,2004)$, essa foi a mola propulsora para a difusão internacional da cozinha francesa, que, por meio dos escritos, passou a ser mais consumida pela leitura do que na mesa, uma vez que a capacidade de ingestão intelectual é maior que a física, e que o público para os textos culinários é imenso. Foi esse público leitor que garantiu o mais sólido fundamento do campo gastronômico, "onde o discurso culinário controla o consumo, que se transforma numa atividade intelectual" (Ferguson, 1998, p. 625).

As ligações entre literatos e gastrônomos, e entre campo literário e campo gastronômico foram vitais para a situação da cozinha entre os produtos culturais franceses e para a posição do campo gastronômico na hierarquia dos campos culturais. O consumo textual da gastronomia pela via das obras literárias foi um elemento crucial para a difusão dos valores que regem o campo, tendo como principal efeito a transcendência do material, que, por meio do discurso literário, se transforma em sensual, passagem que assinala aspectos decisivos na distinção entre cozinha e gastronomia (Ferguson, 1998). A cozinha e os códigos culinários pertencem à produção e têm uma função instrumental. A gastronomia opera com códigos ligados ao consumo, que não têm função instrumental, e sim de discurso. No entanto, esses dois setores estão presentes no campo gastronômico e encontramse ligados à difusão da culinária. 


\section{O MUNDO DOS RESTAURANTES}

Na segunda metade do século XIX, o restaurante se consolida como a principal instituição de difusão e atualização da cultura gastronômica, lugar de criação, produção e consumo. É no interior dele que os chefs, apoiados por suas equipes, desenvolvem e encenam suas propostas, que serão consumidas e avaliadas em seus salões (Huetz de Lemps; Pitte, 1990; Spang, 2003). As propostas legitimadas serão difundidas por intermédio de livros e publicações, passando a circular por outros espaços. A existência de uma cultura gastronômica, desde o século XIX até o início do XXI, está diretamente ligada à existência de um reduto de restaurantes gastronômicos. Assim como a produção das artes visuais é identificada pelas obras expostas nas galerias de arte e nas salas dos museus, a cultura gastronômica se expressa e é reconhecida a partir das salas dos restaurantes especializados.

Outra distinção que merece ser assinalada é a diferença entre campo gastronômico e mundo dos restaurantes. O mundo dos restaurantes é um espaço segmentado, um mercado de alimentação que atende a diferentes públicos. Apenas um segmento dos restaurantes está ligado ao campo gastronômico: o dos estabele- cimentos conduzidos por chefs legitimados por N essa esfera e que operam em sintonia com ela.

¿ Esses chefs, que não produzem em função da demanda do mundo dos restaurantes ou simi plesmente para agradar uma clientela específica, podem ser situados a partir de duas características. Primeiramente eles não são reconhe$\infty$ cidos apenas como os melhores cozinheiros, $\therefore$ mas como aqueles que repensam e definem a จิ maneira como as pessoas vão comer. Não estão preocupados em criar pratos, mas em propor novos conceitos e modos de se relacionar com a comida. Em segundo lugar, as transformações que propõem não são aleatórias, pois elas levam em consideração a história do campo e se constituem em sintonia com os debates correntes entre os pares, uma vez que o reconhecimen- to e a legitimação se produzem no interior do campo. As rupturas e as inovações podem ser gestadas no laboratório das cozinhas, reveladas nas salas dos restaurantes, mas só vão se consolidar quando transformadas em discursos e textos que vão embasar os debates e as disputas simbólicas que movem as transformações do campo da gastronomia. As propostas que despontam desse nicho restrito, mas extremamente prestigiado, costumam ter um impacto bastante amplo, afetando setores da indústria de alimentação, a rede de restaurantes e as cozinhas domésticas nas grandes cidades.

\section{GASTRONOMIA E TURISMO: a era dourada}

Na primeira metade do século XX, a difusão da gastronomia francesa esteve intimamente associada à relação que se estabeleceu entre o desenvolvimento do turismo e os restaurantes gastronômicos, num movimento que transcorreu em dois momentos diferentes, correspondentes a modelos de associação distintos: o turismo internacional da belle époque e o turismo automobilístico a partir de 1920. Entre o final do século XIX e o início da Primeira Guerra mundial, ocorre o turismo internacional da belle époque, quando os muito ricos dos Estados Unidos e da América do Sul, viajando nos novos navios a vapor, promoveram uma expansão da estrutura de hotéis e restaurantes de luxo da Europa (Drouard, 2007; James, 2008; Poulain; Neirinck, 2004). O turismo automobilístico, que levou a uma redescoberta da cozinha regional francesa como patrimônio cultural (Csergo; Lemasson, 2008; Poulain; Neirinck, 2004), implicou um fortalecimento dos guias gastronômicos que, a partir de então, passaram a desempenhar um papel determinante na construção das legitimidades e tendências no interior do campo gastronômico (Cazelais, 2006; Csergo; Lemasson, 2008).

A belle époque é considerada pela maioria dos estudiosos (Drouard, 2007; Ferguson, 
1998; Poulain; Neirinck, 2004) a era dourada da gastronomia francesa. Foi o momento em que o campo gastronômico se fortaleceu em torno dos agentes franceses, os chefs se profissionalizaram e criaram um modelo de reprodução internacional da alta cozinha francesa.

Na segunda metade do século XIX, desenvolveu-se um turismo de luxo entre os europeus em torno dos balneários e das estações de água, que derivou na construção de grandes hotéis, moldados no espírito da cultura palaciana. Projetados por arquitetos e decoradores de renome, tiveram como um dos principais atrativos os seus restaurantes, concebidos pelos principais chefs parisienses. Nesse turismo sazonal, cresceu uma parceria entre profissionais da gastronomia e profissionais hoteleiros, embasando a construção de espaços similares nas principais capitais europeias, nos Estados Unidos e até nos navios, inventando-se uma fórmula que promoveu a desterritorialização do formato do restaurante gastronômico parisiense. Paralelamente, surgiram as escolas de hotelaria, onde a gastronomia despontou como um dos carros-chefe, fixando parâmetros que foram adotados mundialmente. A Escola de Hotelaria de Nice, a primeira delas, fundada em 1902, publicou, em 1918, um tratado assinado por um de seus professores (Louis Leospo), o qual, traduzido para o inglês, italiano, grego, dinamarquês, norueguês e japonês, foi difundido internacionalmente (Poulain; Neirinck, 2007).

A parceria mais famosa e paradigmática foi a que se estabeleceu entre o hoteleiro Cesar Ritz e o chef Auguste Escoffier (James, 2008), que, de certa forma, inspirou todas as demais no período. Iniciaram essa colaboração no Grande Hotel de Monte-Carlo, na década de 1880. A partir de 1890, trabalharam juntos em diversos projetos, entre os quais o dos hotéis Savoy e Carlton de Londres, o Ritz de Paris e o Ritz de Roma. A pedido da companhia de navegação alemã Hambourg Amerika Line, Escoffier criou os menus, contratou pessoal e equipou as cozinhas dos transatlânticos que faziam o percurso entre a Europa e os Estados Unidos. Codificou um modelo internacional de alta co- zinha francesa que foi rigorosamente reproduzido em todos esses lugares. Nos espaços que dirigiu, o menu era sempre escrito em francês, a língua falada na cozinha também era o francês, e a maior parte dos funcionários eram franceses. Mas o principal trabalho do chef, para consolidação e difusão de suas propostas, foi no âmbito das publicações, onde, com auxílio de uma equipe, elaborou um sistema para se pensar e produzir a gastronomia, que, traduzido para diversas línguas, transformou-se na principal referência dos cozinheiros e gastrônomos durante quase todo o século XX.

\section{SÉCULO XX: gastronomia e turismo automobilístico}

Na era dourada, temos um padrão de gastronomia que emana de Paris. A era do turismo automobilístico, com a redescoberta das cozinhas regionais, vai começar a quebrar essa centralidade. Os guias turísticos, que se multiplicaram a partir do século XX, começaram a destacar, ao lado do patrimônio artístico e histórico, o patrimônio culinário de cada região, abrindo o horizonte dos viajantes para uma diversidade de cozinhas. Nos anos vinte, esse processo se acentuou com os guias gastronômicos se autonomizando e passando a delinear uma geografia culinária do país (Csergo; Lemasson, 2008). Nesse contexto, nasceu o Michelin Rouge (Karpic, 2000; Mesplède, 1998), criado com o objetivo de orientar os viajantes, convertendo-se no principal instrumento de legitimação dos espaços gastronômicos no interior do campo, num momento em que ele atravessava uma nova fase de fortalecimento com a criação de associações e academias de gastrônomos ${ }^{4}$ (Ory, 1998). Essas novas instituições, que passaram a legislar sobre o setor, mantendo as fronteiras entre cozinhas cultas e

${ }^{4}$ Entre as mais importantes, podemos mencionar o Club des Cent, criado em 1912, tendo, entre seus principais objetivos, a defesa da cozinha nacional, a Académie des psychologues du goût, datada de 1923, e a Académie des gastronomes, de 1927. 
populares, designando os preceitos da cultura gastronômica, iram também estipular os critérios de avaliação utilizados pelos guias. ${ }^{5}$

Pela primeira vez, temos um diálogo entre a cozinha culta e as cozinhas populares, com a incorporação de elementos das culinárias regionais pela alta cozinha. Não se trata da reabilitação da tradição camponesa ou popular, mas de uma reescrita culta dos pratos regionais. Simultaneamente, ocorreu uma descentralização dos espaços tidos como gastronômicos, até então estabelecidos em Paris, em direção às províncias. Inaugurou-se uma nova fase na história do campo gastronômico, em que as técnicas e produtos originários de diferentes terroirs foram se tornando fontes de pesquisa e renovação para o trabalho dos chefs.

Em 1933, o Michelin Rouge iniciou um processo de avaliação anual dos espaços gastronômicos, utilizando um sistema de estrelas que se transformou no principal instrumento de construção da reputação no interior do campo, com impacto e reconhecimento para além dele, no âmbito da mídia internacional. A partir dos restaurantes estrelados, o guia desenhou a geografia dos espaços gastronômicos, que até os anos 1960 estava restrita à França.
O antropólogo português José Manuel Sobral (2014) assinala que os movimentos de construção de cozinhas nacionais despontaram geralmente sob governos autoritários, como no Portugal de Salazar e na Itália de Mussolini, tendo se materializado apenas no âmbito teórico, por meio de publicações. Foram compilações realizadas com espírito folclorista, quase sempre assinadas por homens das classes superiores, que se cristalizaram em elaborações que refletem mais o gosto pessoal dos autores do que a realidade gastronômica do país.

No Brasil, foi publicada, em 1967, a História da alimentação no Brasil, de Câmara Cascudo (2004). Mariana Corção (2012) observa que, na obra de Cascudo, o elemento de ligação entre as expressões locais é a tradição culinária portuguesa (inventada, visto que ela também é plural), escolhida em função do gosto pessoal do autor. Mais um mito que permaneceu limitado ao livro que, como A cozinha futurista, de F.T. Marinetti e Fillìa (2009), publicada na Itália nos anos 1930, nunca se configurou numa cultura culinária. Appadurai (1988) identifica a mesma tendência de construção de uma cozinha nacional a partir dos livros, na Índia, após o processo de descolonização.

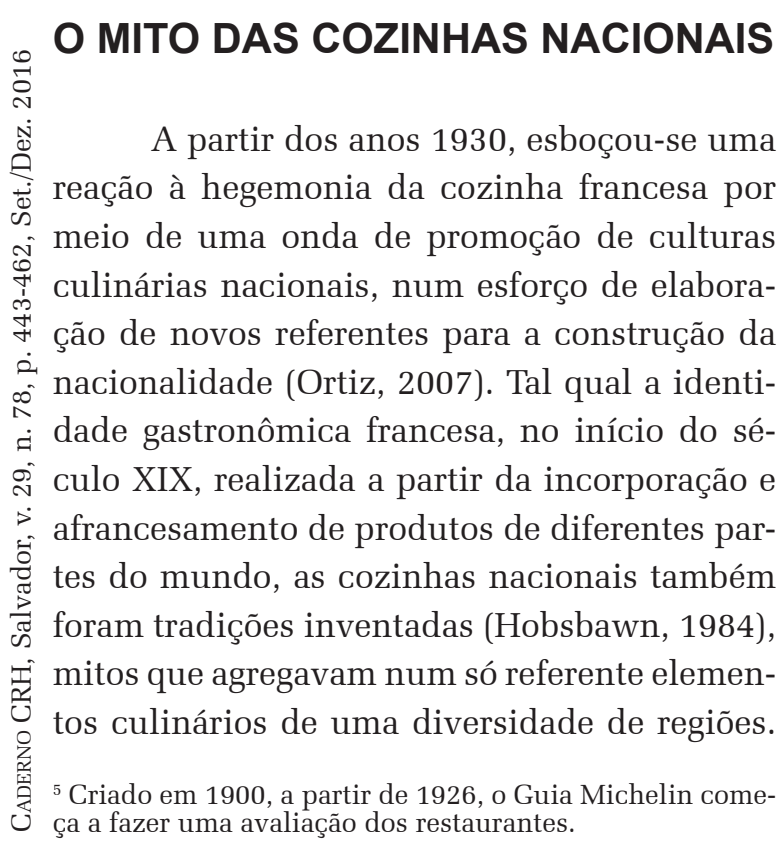

\section{REVOLUÇÕES PARCIAIS NO CAMPO}

Apesar das reações a favor de culturas nacionais, até os anos 1960 o cenário gastronômico permaneceu relativamente estável, com a cozinha francesa pautando-se rigorosamente pela tradição e mantendo o seu prestígio. Mas, a partir dos anos 1970, entramos num período de grandes transformações que acabaram comprometendo a hegemonia da gastronomia francesa. Apontamos, particularmente, dois movimentos, a Nouvelle Cuisine e a Slow Food, que, introduzindo alterações radicais na maneira como os chefs passaram a se relacionar com as tradições e com a instituição gastronômica, de um modo geral, deflagraram revoluções parciais no campo (Bourdieu), mudando a composição de forças em seu interior. 
Nouvelle cuisine: autonomia dos chefs e destradicionalização do campo gastronômico

Se, na cultura acadêmica, a base da produção consistia no domínio do modelo institucional pelos artistas (Heinich, 1993), na cultura modernista, o fundamento da criação passou a ser a autonomia do artista (Bueno, 2001). No novo contexto, regido pela criação e a invenção, as instituições legislam sobre um momento posterior, a recepção, a circulação e o consumo das obras de arte (galerias de arte, crítica de arte e museus). Desde então, esse espírito do modernismo tem predominado em diferentes esferas, das artes à indústria criativa. Porém, na gastronomia - um campo cultural de formação tardia, que se organizou no início do século XX, quando os preceitos elaborados por Escoffier se institucionalizaram em escolas como a Le Cordon Bleu, em Paris -, a observância da tradição ainda orientava o trabalho dos chefs. Em plena década de 1960, as cozinhas se pautavam por normas concebidas no final do século XIX (Drouard, 2007; Poulain; Neirinck, 2004; Rambourg, 2010).

Entre as diretrizes principais, constavam: a) a presença obrigatória de caldos e molhos, fundamento da metodologia de Escoffier; b) a presença de ingredientes arquetípicos e caros, como as lagostas, os camarões, os peixes de rio, as caças nobres (como o faisão), os cremes, a manteiga, entre outros, geralmente franceses; c) o processo de sublimação dos ingredientes, que além dos molhos e caldos, podiam ser flambados, recheados, envoltos em massas folhadas; d) o luxo que se reproduzia na sala de refeições, no número de pratos do menu e na duração da refeição; e) o papel central do garçom no espetáculo de finalização do prato à frente do cliente, flambando, cortando as carnes, trinchando as aves, passando as comidas das travessas decoradas na cozinha para os pratos individuais.

O motor das transformações impostas pela Nouvelle cuisine foi a expansão da autonomia individual no interior do campo gastronô- mico, a partir da construção de novos discursos, que induziram os atores a abandonarem a lógica institucional dominante por novas lógicas e papéis (Rao; Monin; Durand, 2003). Essa mudança de operação levou à erosão da hegemonia da cozinha tradicional francesa.

O surgimento da Nouvelle cuisine é um exemplo perfeito do que Anthony Giddens designa de reflexividade institucional ${ }^{6}$ (Giddens, 2002), que faz com que todo conhecimento novo produzido sobre a estrutura social tenda a alterar substancialmente, e de forma imprevisível, sua dinâmica. As contínuas informações sobre a realidade social, em lugar de reforçar os mecanismos de controle, como se previa, derivaram num movimento de instabilidade. "A produção de conhecimento sistemático sobre a vida social torna-se integrante da reprodução do sistema, deslocando a vida social da fixidez da tradição" (Giddens, 1991, p. 59). A nova corrente não foi impulsionada por um chefe de cozinha, mas por dois críticos, Gault e Millau, responsáveis por um dos guias gastronômicos de maior prestígio, que lançaram, em 1973, um desafio pela renovação e modernização da culinária, propondo alguns novos mandamentos que atacavam os pilares da tradição gastronômica francesa.

Começaram desvinculando a alta gastronomia do mundo do luxo, à qual estava associada, minimizando a importância dos cenários requintados e dos produtos caros, para enfatizar o talento do chef. Em março de 1973, sob o título de À l'ouest du nouveau, anunciam uma transformação na geografia gourmande de Paris, chamando atenção para uma nova geração de chefs que despontava na periferia da cidade, ${ }^{7}$ praticando uma cozinha inventiva, com

${ }^{6}$ O problema da reflexividade, para Anthony Giddens, está no centro da análise da dinâmica da vida social na alta modernidade. A reflexividade se manifesta em diversos aspectos: 1 . no entrelaçamento das instituições modernas com a vida individual, na interação entre influências globalizantes de um lado e disposiçôes pessoais de outro; 2 . nos processos de reorganização do tempo e do espaço, associados a mecanismos de desencaixe - mecanismos que descolam as relações sociais de seus lugares específicos, recombinando-as através de grandes distâncias no tempo e no espaço.

${ }^{7}$ Entre os chefes apontados nesta matéria por Gault e Millau, estavam Michel Guérard e Claude Verger. 
um cardápio reduzido, instituindo um novo estilo baseado na simplicidade. Alguns meses depois, em outubro, publicam outro artigo formulando o que passaram a designar como os dez mandamentos da Nouvelle Cuisine. Entre eles, constavam: a defesa de uma gastronomia mais leve; a valorização dos produtos frescos disponíveis no mercado; a utilização de novas técnicas e tecnologias; a abolição de anacronismos, como os temperos pesados e os cozimentos excessivos, resíduos de épocas em que as cozinhas não dispunham de sistemas de refrigeração (Rambourg, 2010).

A adesão entusiasmada de um grupo de chefes gerou uma verdadeira revolução, promovendo uma nova maneira de fazer cozinha: não mais a partir da tradição, mas de um projeto ligado a um conceito de gastronomia concebido a partir dos estilos de vida, das tecnologias, do estudo das novas possibilidades das tradições e dos ingredientes, mas, sobretudo, das novas demandas da sociedade de consumo (Franco, 2006; Rambourg, 2010; Suaudeau, 2007).

A proposta se difundiu rapidamente para os Estados Unidos, para países do Oriente Médio e de outras partes da Ásia. O entusiasmo pelo exotismo, pela experimentação e pela invenção estreitou as colaborações, intensificou o processo de trocas, promovendo o fortalecimento de $\circ$ uma uma nova prática: as hibridações. Nesse quesito, um destaque foi a forte influência da cozinha japonesa sobre a cozinha ocidental, modificando as técnicas de cozimento, a maneira de lidar com os produtos, o serviço nos restaurantes e a estética dos pratos (Rambourg, 2010).

\section{Slow food}

O movimento Slow food surgiu em Roma, em 1989, liderado pelo jornalista, sociólogo e crítico de gastronomia Carlo Petrini, como uma reação contra o sistema de Fast food e a indústria da alimentação. Para Petrini, a gastronomia, trabalhando a partir do sabor e do prazer, pode ajudar a modificar os hábitos alimentares dos consumidores, reinventando o ato de comer, desenvolvendo um projeto culinário comprometido com a preservação da biodiversidade e a defesa do trabalho de pequenos produtores. Ou seja, criando "uma nova gastronomia, a serviço do prazer dos sentidos (BOM), do respeito à terra (PRÓPRIO) e da existência digna dos camponeses (JUSTO)" (Petrini, 2006, p. 6, destaque do autor). Citando Brillat-Savarin, legitima sua posição estabelecendo uma ligação com o discurso original da fundação do campo gastronômico francês.

\begin{abstract}
Minha tese é simples: a gastronomia pertence ao domínio das ciências, da política e da cultura. Contrariamente ao que se acredita, ela pode constituir uma ferramenta política de afirmação das identidades culturais e um projeto virtuoso de confronto com a globalização em curso.

A gastronomia nos conduz a um saber interdisciplinar e complexo. Interessar-se por 'tudo aquilo que é relativo ao homem enquanto ser que se nutre' (Brillat-Savarin) exige conhecimentos nos domínios da antropologia, da sociologia, da economia, a química, a agricultura, a ecologia, a medicina, os saberes tradicionais e as tecnologias modernas.

Tal corpus científico amplia enormemente o papel reservado aos gastrônomos. Ao mesmo tempo, aumenta o círculo de pessoas que deveriam estudá-lo para melhor governar, melhor confrontar os problemas atuais ou, ainda mais simplesmente, melhor compreender nosso mundo. Como defende Wendell Berry, o poeta-camponês do Kentucky, 'comer é um ato agrícola' (Petrini, 2006).
\end{abstract}

Trabalhando para a consolidação do movimento, Carlo Petrini viajou o mundo, fez parcerias, conquistou o reconhecimento dos grupos ecológicos, de associações e núcleos de pequenos produtores agrícolas e da nata dos chefs de cozinha, conseguindo com que a sua filosofia 
fosse incorporada pelo campo da gastronomia.

Na edição francesa de seu livro Bon, propre et juste. Éthique de la gastronomie et souveraineté alimentaire, publicada em 2006, o prefácio foi assinado por Alain Ducasse, o mais renomado e globalizado dos chefs franceses. ${ }^{8}$ Para Ducasse, nesse novo quadro, o cozinheiro se transforma num militante do produto. Ele deve estabelecer um diálogo com todos os seus produtores. Sua exigência deve encorajá-los a perseverar, em suas pesquisas, produtos bons, próprios e justos. Em retorno, os produtores poderão lhe proporcionar a descoberta de variedades de frutas ou legumes que tínhamos esquecido ou de carnes particularmente saborosas (Ducasse; Lheritier, 2006).

Em 1998, a UNESCO declarou a tradição culinária como patrimônio imaterial da humanidade $^{9}$ (Sobral, 2014). Em 2002, a Slow food, num esforço de patrimonialização dos produtos gastronômicos, criou uma comissão internacional para implantar a "Arca do Gosto":

[...] um catálogo mundial que identifica, localiza, descreve e divulga sabores quase esquecidos de produtos ameaçados de extinção, mas ainda vivos, com potenciais produtivos e comerciais reais. O objetivo é documentar produtos gastronômicos especiais, que estão em risco de desaparecer. Desde o início da iniciativa em 1996, mais de 1.000 produtos de dezenas de países foram integrados à Arca. Este catálogo constitui um recurso para todos os interessados em recuperar raças autóctones e aprender a verdadeira riqueza de alimentos que a terra oferece (ARCA..., 2007).

Em 2004, foi instituída a rede Terra Madre, que realiza eventos anuais com pequenos produtores de comunidades agrícolas de cinco continentes, tendo como convidados cinquenta dos mais proeminentes chefs globais. $\mathrm{O}$ movimento acentuou as diferenças entre os projetos no campo da gastronomia. Embo-

${ }^{8}$ Alain Ducasse é proprietário e responsável pelo conceito de 25 restaurantes gastronômicos em diferentes cidades do mundo, e é o primeiro chef a manter, simultaneamente, três restaurantes com três estrelas no Guia Michelin.

${ }^{9}$ Em 2005 o governo francês declarou o foie gras como patrimônio cultural e gastronômico francês e, em 2010, inscreveu "a refeição gastronômica francesa" como patrimônio da humanidade. ra as técnicas e a metodologia de preparo da alta cozinha sejam partilhadas por todos, por meio das publicações e dos inúmeros eventos anuais que reunem chefs de vários países, o repertório de ingredientes utilizado por cada um deles é cada vez mais diversificado (Poulain, 2004). Entre as principais fontes que alimentam esse processo de diferenciação e reinvenção da gastronomia contemporânea estão as práticas culinárias regionais.

\section{GLOBALIZAÇÃO DOS PROCESSOS DE AVALIAÇÃ̃O E CONSAGRAÇÃO DA GASTRONOMIA ${ }^{10}$}

Todas essas transformações repercutiram sobre os processos de avaliação e consagração das altas cozinhas. Primeiramente, temos o surgimento de novos guias, reconhecidos como instrumentos de validação institucional legítimos, que apresentam diferentes pontos de vista relacionados com as mudanças ocorridas nas regras da cozinha. O Guide Rouge Michelin, embora mantenha o prestígio, perdeu a centralidade. Lembramos que o movimento da Nouvelle cuisine foi deflagrado por um novo guia, o Gault et Milliau, com critérios distintos do Michelin. Nesse quadro, estabelece-se uma disputa entre os guias pelo monopólio da avaliação no domínio da gastronomia. Mas todos eles convergem na defesa da instituição gastronômica, embora por vias divergentes em alguns aspectos, num processo que Pierre Bourdieu denomina de "concorrência pela legitimidade" no interior do campo (Bourdieu, 2007). Assim, reafirmaram a validade da instituição gastronômica, mas desvinculando seu exercício dos parâmetros da tradição francesa, deslocamento que levou a uma mudança de regras no interior das cozinhas, ampliando consideravelmente o espaço geográfico de produção. Uma gastronomia pautada pela ${ }^{10}$ Os dados apresentados neste segmento do texto foram
coletados a partir da pesquisa sobre os guias gastronô-
micos e revistas especializadas, realizada nas bibliotecas
francesas em 2015 e 2016, com apoio da CAPES. 
autonomia e criatividade dos chefs, pela valorização dos ingredientes frescos e de novos sabores (Nouvelle cuisine) e associada à preservação da biodiversidade e do trabalho dos pequenos produtores (Slow food), não depende mais do terroir francês, pois pode ser realizada em qualquer canto do planeta, de preferência em regiões onde prospera uma biodiversidade rica. Desde então, o campo da gastronomia vem evoluindo como um espaço segmentado, organizado em torno de diferentes tendências.

Num segundo momento, a esfera de avaliação se desloca da França para o espaço global. Em 2002, a revista inglesa Restaurant Week instituiu uma nova metodologia de avaliação, promovendo um ranking mundial dos melhores restaurantes, The 50 World's Best Restaurants, que ultrapassou o guia francês em termos de consagração. Enquanto o Michelin opera a partir de inspetores anônimos, a seleção inglesa é realizada pelos pares (chefs, gastrônomos, jornalistas especializados, críticos, etc.), em diferentes partes do mundo. Trata-se de um corpo de jurados identificado, que compõe uma espécie de academia global da gastronomia.

Embora os chefs franceses mantenham uma posição respeitável na avaliação da Restaurant Week, eles perderam o protagonismo. Desde 2002, entre os dez melhores, não consta ๑ nenhum francês. Nos primeiros anos, predominaram os ingleses, os norte- americanos e, principalmente, os espanhóis. Recentemente, os espanhóis vêm dividindo espaço com os latino-americanos e asiáticos. Na primeira década deste século, o catalão Ferran Adria foi promovido a melhor chef do mundo. Nas últimas listas, o chef dinamarquês René Redzepi tem se destacado nessa posição.

Sintonizado com a nova dinâmica, o Michelin também assumiu um caráter global. No final do século XX, já incluía a Europa, nos anos 2000 estendeu-se para a Ásia e os Estados Unidos, e, após 2010, passou a abranger a América Latina, sendo que a primeira edição do Guide Rouge para São Paulo e Rio de Janeiro foi publicada em 2015. A França permanece com grande protagonismo; porém, na seleção mundial dos restaurantes estrelados avaliados pelo Michelin, os chefs franceses ocupam o segundo lugar. Em primeiro lugar, como os chefs mais estrelados do mundo, estão os japoneses.

\section{BIODIVERSIDADE OU O PLANETA COMO REFERENTE GLOBAL}

A estratégia bem-sucedida da Slow food, atribuindo uma função política à gastronomia - papel-chave no movimento de defesa da biodiversidade e da sustentabilidade das culturas camponesas no planeta -, gerou uma mudança definitiva na dinâmica de construção da identidade no interior desse universo. Conforme Renato Ortiz (2007, p. 13), “[...] toda identidade é uma construção simbólica que se faz em relação a um referente, e há certamente uma multiplicidade deles: étnicos, nacionais, de gênero. Os relatos universais, para construírem suas centralidades, necessitam de um referente mundial". A tradição clássica francesa, um referente nacional, que até pouco tempo unia o campo, foi substituída por um outro de âmbito universal: o discurso pelo engajamento do trabalho dos chefs na recuperação do planeta. Mas essa tarefa se efetiva a partir das diversidades regionais. Portanto, trata-se de um referente universal que promove a diferenciação e também a desterritorialização, aprofundando um processo deslanchado pela Nouvelle cuisine. Desde então, o movimento de circulação ficou mais acentuado. Todos viajam o tempo todo. Viagens para descobrir novos produtos, para mostrar o trabalho, para ver o trabalho dos outros, para desenvolver projetos em colaboração.

Respondendo ao desafio lançado pela Slow food, uma nova elite de chefs vem se promovendo em viagens de pesquisa pelo mundo com o intuito de identificar novos produtos e localizar pequenas comunidades de camponeses esquecidas. Nessa nova configuração, os que residem em regiões onde predomina uma biodiversidade rica e núcleos de tradições regionais 
ativos, como os latino-americanos, por exemplo, encontram-se numa posição privilegiada em relação aos europeus. Desde então, agrega-se um novo pré-requisito à condição de chef bem-sucedido, além de artista-criador, em conformidade com a nova ideologia do campo: ele deve ser também promotor de utopias, trabalhando em conexão com os pequenos produtores e ajudando a preservar a biodiversidade do planeta.

\section{NOVA GASTRONOMIA BRASILEIRA}

No fluxo dessas mudanças, nos anos 1990, despontou a primeira geração de chefs brasileiros (Bueno, 2013) afinados com o movimento global: combinando o uso das técnicas e metodologias da gastronomia contemporânea com práticas e ingredientes das cozinhas regionais, praticamente esquecidos, inventaram o que se passou a designar como nova gastronomia brasileira. Iniciam um trabalho de pesquisa e revitalização de produtos e cozinhas de diferentes regiões do Brasil, com um destaque para as tradições culinárias mineiras e nordestinas, e os produtos da Amazônia, que, por meio de um processo de retradicionalização (Giddens, 1991, 1997), ressurgem dentro de práticas culinárias distintas das receitas regionais às quais, até então, estavam atrelados. Os novos chefes brasileiros praticam uma culinária contemporânea e globalizada e, além de recorrerem aos perfumes e sabores locais como elementos de diferenciação, procuram construir um estilo próprio. Sobre esse esforço é revelador o comentário de Alex Atala, um dos pioneiros dessa geração:

A cozinha francesa dos grandes chefes, nos últimos anos, se assemelha a um filme de Hollywood: bem feito, mas sem emoção. Há um ritual no comer que é muito formal e só. A mesa é a grande emoção da gastronomia. É preciso cozinhar com alma, provocar, surpreender todos os sentidos sempre. Desestruturar, olhar o conceito, desmembrar, buscar na raiz e trazer a mesma receita com uma nova proposta no momento oportuno. Não somos franceses e não queremos ser franceses (Atala apud Doria, [20--]).
A incorporação de ingredientes nativos e de fácil acesso no mercado viabilizou economicamente a gastronomia para um público mais amplo, que tem acompanhado essas transformações pelos programas ministrados por chefs na televisão, contribuindo para a sua difusão no país.

Trata-se da primeira geração de chefs no Brasil, vinda da classe média e média alta, que não surgiu a partir das cozinhas dos restaurantes. ${ }^{11}$ Para a maior parte deles, a gastronomia apareceu como uma nova opção, num fase de crise e transição da vida profissional. Muitos viveram essa mudança na Europa e nos Estados Unidos, onde se iniciaram nos anos 1990, tendo passado também por cursos e estágios em restaurantes inovadores estrangeiros.

Entre 1999, quando Alex Atala (1968) um dos pioneiros do núcleo - fundou o restaurante D.O.M. em São Paulo, e 2016, esse universo se expandiu, consolidou-se e foi reconhecido no campo gastronômico global. O sucesso rápido do empreendimento se deve a vários fatores, além do talento e da criatividade individual, dentre os quais destaco: 1) o interesse crescente das principais correntes globais pela biodiversidade da América Latina e seus produtos, que alçou não apenas os brasileiros, mas os peruanos, os mexicanos e os chilenos; 2) a capacidade dos chefs brasileiros de construir uma fusão bem sucedida entre cultura global e ingredientes locais, destradicionalizando as referências regionais, de forma a torná-las compreensíveis para um público consumidor de fora do país, e 3) a competência deles próprios para se inserirem no circuito global, justificando seu trabalho a partir de um discurso sintonizado com as ideologias correntes no campo gastronômico, utilizando com propriedade a mídia para o processo de

${ }^{11}$ Fizemos uma pesquisa e organizamos uma tabela com informações sobre a trajetória e formação de 17 chefs brasileiros com circulação global, que foram selecionados a partir das classificações realizadas entre 2015 e 2016 pelos seguintes guias e rankings: Guia Michelin Rouge Rio de Janeiro \& São Paulo, Guia Quatro Rodas, 50 Best World/Restaurant Week e 50 Best Latin American/Restaurant Week. Muitas informações apresentadas neste segmento do texto foram extraídas deste material. 
divulgação do trabalho e do discurso.

A trajetória de Atala ilustra bem a rápida projeção da gastronomia brasileira. Em 2006, seu restaurante, com menos de dez anos, foi incluído entre os 50 melhores no ranking elaborado pela revista Restaurant Week. A partir de 2011, passou a constar entre os dez melhores do mundo, na mesma publicação. A seguir, apareceu na relação das cem personalidades de maior destaque em 2014, elaborada pela revista Time, onde foram incluídos apenas dois brasileiros, Atala e Joaquim Barbosa. Em novembro de 2014, juntamente com dois outros chefs, um norte-americano e um dinamarquês, foi capa da mesma revista Time sob a legenda "The Gods of Food. Meet the people who influence what (and how) you eat". Tem cinco livros publicados, entre os quais D.O.M. Redescobrindo os ingredientes brasileiros (2013), com prefácio de Alain Ducasse, e Gastronomia+Brasil+Reflexões (2015), editado pela Phaidon Books em três versões, inglês, francês e português.

A publicação de 2013 deixa transparecer esse esforço de ligação entre a ideologia do campo e as configurações locais na formação de um padrão global. Um bom exemplo é a maneira como Alain Ducasse apresenta o livro de Atala, situando a matriz principal do trabalho na cultura francesa, mas valorizando a pesquisa em torno dos produtos locais, onde o país é visto como uma despensa:

[...] descobre a culinária na Europa. Ele aprende as técnicas clássicas, especialmente as técnicas francesas. Conscientiza-se do fato de que, na culinária francesa contemporânea, as técnicas são consideradas secundárias em relação aos ingredientes. Ao retornar ao Brasil, no início dos anos 1990, ele olha ao seu redor e pensa: onde estão os ingredientes nos quais irei aplicar essas novas técnicas? Eles existem, é claro, mas estão longe - não apenas em termos geográficos, mas também psicológicos. São ingredientes simples, usados por pessoas humildes, muito distantes das práticas urbanas, aceitas no mundo da cozinha internacional.

Vejo o fenômeno de chefs buscando redefinir a importância da terra e do lugar como o fenômeno mais importante que acontece hoje no mundo da gastronomia. Tanto no Brasil - tendo sido Alex uma de suas figuras pioneiras -, como também em muitos outros países, temos chefs aproveitando a despensa única de seu país (Ducasse, 2013, p. 9-10).

Por outra via, na mesma obra, Atala faz um esforço para conciliar a adesão ao padrão global com a construção de uma identidade brasileira, criando uma mitologia que se inicia na sua infância, e que se estende da cozinha à sala do restaurante:

\begin{abstract}
Meu registro cultural é brasileiro. Em algum momento do meu percurso, entendi que ninguém poderia fazer cozinha brasileira tão bem quanto eu, pois os sabores selvagens fazem parte da minha vida desde muito cedo, desde a minha primeira infância. Sou filho e neto de pescadores e caçadores, portanto andar no mato e explorar sabores selvagens fazem parte da minha maneira de ser desde sempre.

[...] o D.O.M. evolui e foi ganhando a identidade de um restaurante brasileiro. No salão, ele é tão brasileiro quanto possível, do sabonete usado nos banheiros - feito no Brasil, à base de castanha - às cadeiras, conhecidas como cadeiras Oscar - uma homenagem do designer Sergio Rodrigues ao arquiteto Oscar Niemayer - tudo exala Brasil (Atala, 2013, p. 11-12).
\end{abstract}

\section{CONSUMO E GLOBALIZAÇÃO}

A gastronomia, no mundo contemporâneo, embora dirigida ao consumo, continua se organizando como um campo cultural, onde o que está em jogo não é a venda imediata da refeição, mas a criação e a invenção de um produto cultural que pretende influenciar os estilos de vida à mesa. No centro desse universo está o chef, o artista da cozinha, autor de novos conceitos (Ferguson, 2004; Ory, 1998; Poulain; Neirinck, 2004). O restaurante é a vitrine, a galeria onde expõe sua obra, o espaço onde acontece a teatralização da produção gastronômica. Embora visando a atingir o público e a mídia, trata-se do que Pierre Bourdieu designou como um mercado de bens restritos, por meio do qual o chef está sempre dialogando em primeira instância com seus pares, ou seja, os outros chefs, os teóricos de gastronomia e os críticos, que, na maior parte das vezes, atuam a partir 
de publicações de circulação restrita.

A principal condição para um reconhecimento mais amplo é o reconhecimento pelos pares, que acontece em duas etapas. A primeira, que precede a abertura do restaurante, consiste na realização de estágios, disputadíssimos, nas cozinhas dos chefs mais reputados no momento. Esses estágios, geralmente realizados após a formação em alguma escola, são momentos de aprendizagem (domínio dos códigos, metodologias e discursos) e de construção de uma rede de relações. A pesquisa que realizamos sobre os jovens chefs brasileiros com reconhecimento internacional aponta que a maior parte deles passou por esse percurso. Dos dezessete chefs estudados, dos quais três estrangeiros e catorze brasileiros, apenas dois deles não percorreram esse itinerário. Roberta Sudbrack (Estrela no Guia Michelin e classificada entre 50 Best's Latin America pela revista inglesa Restaurant Week) teve uma história singular, iniciando-se como chef do palácio da Alvorada, durante a gestão de Fernando Henrique Cardoso. Autodidata, realizou sua formação por meio de leituras e viagens. Outro caso é o de Rodrigo Oliveira (entre os 50 Best's Latin America), que transitou entre a formação no SENAC e a gestão do Mocotó, restaurante de cozinha nordestina de seu pai, que reinventou sob a ótica da gastronomia contemporânea, mas preservando o caráter tradicional. Oliveira vai se projetar internacionalmente a partir de 2013, com o restaurante Esquina do Mocotó, onde produz uma cozinha criativa, com ingredientes e práticas nordestinas, mas sem compromisso com a tradição. A pesquisa de Raul Matta (2010) em torno dos novos che$f_{s}$ peruanos, que estão despontando como as grandes estrelas da gastronomia global, indica que seguiram a mesma trajetória.

Numa segunda etapa, após assumir o posto de chef em um restaurante ou à frente de seu próprio estabelecimento, o discurso do autor justificando a importância do seu trabalho e explicitando a relação de sua proposta com as ideologias correntes dentro do campo é fundamental e estratégico. Esse fato transparece na uniformidade do discurso de chefs de diferentes lugares, principalmente entre os mais jovens. Se, nos anos 1950, todos falavam a mesma língua, a da cozinha francesa clássica, hoje em dia, na era da Slow food, as cozinhas são reconhecidas pela sua diversidade cultural, que deve ser construída com a incorporação de práticas e ingredientes locais, trabalhados a partir das técnicas e metodologias correntes no campo globalizado. Quanto mais original e mais singular for o resultado dessa hibridação, maior é o reconhecimento.

Mas, ao contrário de outros campos culturais articulados ao mercado de bens restritos, como as artes visuais e a literatura, não ocorre descontinuidade entre o reconhecimento cultural e o reconhecimento econômico. Um está ligado ao outro. Mesmo porque os principais instrumentos de legitimação da gastronomia são os guias gastronômicos, que têm uma função comercial, de orientar e informar o cliente da publicação. Além disso, a manutenção do padrão da cozinha e do serviço em um restaurante gastronômico, apesar das simplificações recentes, ainda envolve um investimento muito alto. No caso daqueles com três estrelas atribuídas pelo Guia Michelin, que se destacam também pela decoração suntuosa, os custos são ainda mais elevados.

Com isso, está ocorrendo uma grande mudança, com os espaços estrelados, convertendo-se numa marca que se projeta como vértice de uma grande empresa, com atividades diversificadas. É o caso dos franceses Lênotre e Ducasse, que estão à frente de redes de hotéis, brasseries, confeitarias, boutiques gourmets e escolas, espalhadas por diferentes cidades do mundo. Outros vêm optando por se manter em pequenos espaços com uma ou duas estrelas, onde possam desenvolver as suas pesquisas com menos despesas e atingir um público mais interessante, com menor orçamento, mas com maior capital cultural (Marcilhac, 2012; Terrance, 1996). 


\section{MUNDO DOS RESTAURANTES E RETRADICIONALIZAÇÃO}

Apesar de universos distintos, desenvolve-se uma relação estreita entre o mundo dos restaurantes e campo gastronômico. Até os anos 1970, operavam como uma via de mão única, com a rede de restaurantes passando por reciclagens regulares ao incorporar sistematicamente algumas inovações introduzidas pela alta cozinha internacional.

No contexto contemporâneo, altamente reflexivo, o impacto se dá nos dois sentidos, particularmente porque, hoje em dia, muitos chefs mais jovens atuam nos dois eixos. Mantêm um restaurante gastronômico conceito, constantemente sob a avaliação dos pares e da crítica, e capitalizam o prestígio agregado nesses espaços para anexos com a mesma proposta, mas mais econômicos, como fazem muitos parisienses. Os norte-americanos, os espanhóis e os brasileiros investem diretamente em espaços populares, reinventados a partir de seus conceitos, com grande sucesso de público e altos rendimentos, o que dificilmente conseguiriam alcançar com suas casas principais. O irmão de Ferran Adria abriu um balcão de tapas em Barcelona. Muitos chefs nova-iorquinos têm hamburguerias. Em São Paulo, o chef - japonês Jun Sakamoto abriu a Hamburgueria N Nacional e um balcão de sushis mais econôđं mico. Alex Atala mantém, além do D.O.M., o Dalva e Dino, de comida brasileira, e o Riviera, i um bar tradicional, que reabriu com um cardápio de sanduíches e pratos rápidos com o toque do chef. As publicações e os programas s. de televisão acentuam esse trânsito.

ntes, nas grandes cidades, no século

XXI, tem evoluído em dois sentidos: de um lado, revelando um fortalecimento inédito das cozinhas locais; de outro, trazendo um grande cosmopolitismo, com o aparecimento de uma diversidade de cozinhas de diferentes regiões do mundo (Abbot, 2014; Bak, 2015; Sobral, 2014). Entre os dois, desponta uma terceira tendência de fusão entre elementos de diferentes cozinhas. Recorrendo a essa dinâmica, a cultura culinária dos restaurantes, incorporando a liberdade e a criatividade dos espaços gastronômicos, converteu-se num organismo vivo, em constante processo de renovação e hibridação. Com isso, atendem à demanda de inovação do público consumidor mais recente, sempre em busca de novas experiências e novos sabores, ao contrário dos consumidores mais antigos, que buscavam sempre o mesmo, ou seja, a repetição dos mesmos sabores. Nos restaurantes populares brasileiros, onde predominam a comida a quilo e o bufê a preço fixo, cada um é o seu próprio chef, acionando um processo de hibridação que pode ser ainda mais radical.

Outro exemplo de reflexividade são as redes recentes de "Comida Típica", no Equador (Abbot, 2014). Na verdade, trata-se de uma aplicação padronizada dos métodos da nova gastronomia globalizada, realizada com produtos tradicionais do país. Assim, satisfizeram a demanda de exotismo da clientela, com uma cozinha leve e econômica, que os locais podem comer no meio do dia e que não assusta os turistas.

Boa parte dos chefs contemporâneos alimenta seu repertório de inovações viajando para lugares escondidos nos seus países, atrás de práticas locais e ingredientes esquecidos ou desconhecidos. Essas pesquisas são responsáveis por parte da originalidade e do aumento do prestígio dos chefs latino-americanos e asiáticos.

Os europeus, como não têm essa possibilidade, têm se deslocado para outros territórios. No início dos anos 2000, o chef catalão Ferran Adria, na época considerado o melhor do mundo, fez uma viagem de pesquisa para a Amazônia, cercada de grande publicidade. Em 2016, o chefe dinamarquês do restaurante Noma, René Redzepi, que, nos últimos anos, apareceu várias vezes no ranking da revista inglesa Restaurant Week como o melhor do mundo, fechou o seu restaurante em Copenhague temporariamente, para passar uma temporada 
de cinco meses com toda sua equipe na Austrália. A proposta era montar um restaurante efêmero em Sidney, a fim de realizar um único jantar, com um cardápio de doze pratos, inteiramente baseado em produtos nativos, cozinhados à la "Noma". O objetivo foi o de colaborar com os chefs australianos, ajudando-os a descobrir o potencial gastronômico dos produtos aborígenes, até então desprezados, como observa Redzepi (apud Labro, 2016, p. 53-54):

[...] os australianos não comem a sua própria paisagem, porque ela está associada aos aborígenes, e os australianos brancos preferem se manter voltados para a Europa. Uma história complexa, que não é a minha.

$[\ldots]$

Nós lemos muito antes, viajamos bastante através de todo país, para descobrir e escolher os produtos que utilizamos. Percorremos os desertos, as florestas tropicais, encontramos as comunidades aborígenes, trocamos e comemos com eles. Experimentamos caranguejo grelhado, rabo de canguru cozido na sua pele, ervas selvagens e pimentas do mato, dezenas de conchas e crustáceos desconhecidos.

O evento, de grande repercussão na mídia, cumpriu sua finalidade. Legitimando os produtos da paisagem aborígene, deverá contribuir para o projeto de uma nova gastronomia australiana, como relatam a seguir dois jovens chefs de Sidney e Melbourne:

Às vezes, precisamos de alguém de fora para nos revelar o que temos no interior. [...] Ele nos fez refletir. Eu saí de lá me dizendo: mas o que nós fizemos? Por que não utilizamos mais os nossos produtos, em vez de todas essas coisas exóticas como o foie gras ou a trufa? René Redzepi vem a ser o primeiro a nos abrir os olhos sobre a importância de utilizar os ingredientes daqui (Kwong apud Labro, 2016, p. 54). O que é a cozinha australiana? Ninguém pode responder esta pergunta por enquanto. Mas temos em mão um leque infinito de produtos extraordinários, próprios da Austrália, e nos beneficiamos de técnicas vindas da França, da Itália, do Japão, da Coreia... Podemos aplicar esse conhecimento culinário vindo de fora a todos os ingredientes que estão aqui desde sempre. Foi isto que o 'Noma' fez, e é isto que muitos de nós aspiramos a fazer hoje (Stone apud Labro, 2016, p. 54).
A passagem de Redzepi pela Austrália é reveladora do processo de retradicionalização em curso no interior da gastronomia contemporânea, em que, no caso, o que está em jogo é apenas a valorização global da alta cozinha australiana. Os produtos da paisagem nativa, transformados simbolicamente pelo trabalho do chef dinamarquês, dissociaram-se da cultura aborígene e foram revelados para os chefs locais revestidos de uma nova legitimidade, despidos de todas as suas referências culturais. É bastante semelhante ao movimento da nova gastronomia peruana, descrita por Raul Matta (2010), em que os chefs, descendentes das elites europeias que colonizaram o Peru, constroem uma fusão bem sucedida das metodologias apreendidas na Europa e nos Estados Unidos com os ingredientes e práticas das cozinhas populares peruanas. Como observa Matta (2010), o que está em jogo não é a valorização da cultura popular, mas a projeção da cozinha culta peruana.

O processo de mundialização da gastronomia se efetiva em duas etapas distintas: a internacionalizada, até os anos 1960, e a globalizada, a partir dos anos 1980. No primeiro período temos um processo de circulação que parte dos países centrais para os periféricos. Ou seja, no caso da cultura gastronômica o padrão é construído na França e exportado para o resto do mudo. Desde os anos 1980, assistimos à constituição de uma dinâmica de circulação globalizada, dominada pela reflexividade institucional. Nessa configuração, o padrão da cultura gastronômica se constitui no espaço global, num processo de transformação mais acentuado e indeterminado, pautado por um embate entre diferentes tendências e referências em circulação no fluxo mundial.

Recebido para publicação em 21 de abril 2016 Aceito em 19 de setembro de 2016 


\section{REFERÊNCIAS}

ABBOTS, J. The fast and fusion: class, colonialism and remaking of "comida típica" in high land Ecuador. In: KLEIN, J. A.; MURCOTT, A. (Ed.). Food consumption in global perspective. Basingstoke: Palgrave Mcmillan, 2014.

APPADURAI, A. How to make a national cuisine: coockbooks in contemporary India. Comparative studies in society and History, v. 30, n. 1, p. 3-24, 1988.

. Modernity at large: cultural dimension of globalisation. Minneapolis: University of Minnesota Press, 1996.

ARCA do gusto. 2007. Disponível em: http://www. slowfoodbrasil.com/arca-do-gosto. Acesso em: 1 fev. 2016

ATALA, A. D.O.M. Redescobrindo ingredientes brasileiros. São Paulo: Melhoramentos, 2013. 292 p.

BAK, S. Exoticizing the familiar, domesticating the foreign: ethnic food restaurants in Korea. In: OK KIM, K. (Ed.). Reorientating cuisine: east-asian foodways in the twenty-first century. New York: Oxford: Berghahn, 2015.

BARBOSA, L. Tendências da alimentação contemporânea, 2013. 44 p. Mimeografado.

BONNET, J. C. Le système de la cuisine et du pas chex Rousseau. Poétique, v. 22, p. 24-67, 1975.

Carême ou les derniers feux de la cuisine décorative. Romantisme, v. 17, n. 18, p. 23-24, 1977.

BOURDIEU, P. As regras da arte. São Paulo: Companhia das letras, 1996.

A distinção: crítica social do julgamento. Porto Alegre: Zouk; São Paulo: EDUSP, 2007.

BRILLAT-SAVARIN, J. A. A fisiologia do gosto. Tradução de Paulo Neves. São Paulo: Companhia das letras, 2005.

BUENO, M. L. Artes plásticas no século XX: modernidade e globalização. Campinas: Unicamp, 2001.

. Do moderno ao contemporâneo: uma perspectiva sociológica da modernidade nas artes plásticas. Revista de Ciências Sociais, Fortaleza, v. 41, n. 1, 2010, p. 27-47.

Gastronomia e sociedade de consumo: tradições culturais brasileiras e estilos de vida na globalização cultural. In: REINHEIMER, P.; SANT'ANNA, S. P. (Org.). Manifestações artísticas e ciências sociais: reflexões sobre 6 arte e cultura material. Rio de Janeiro: Cultis 2013.

; CAMARGO, L. O. (Org.). Cultura e consumo: estilos ; de vida na contemporaneidade. São Paulo: Senac, 2008.

CANCLINI, N. G. Culturas híbridas: estratégias para entrar e sair da modernidade. São Paulo: Edusp, 1996.

i CASCUDO, L. C. História da alimentação no Brasil. São \& Paulo: Global, 2004.

F CHENLA, G. L'Evolution récente des restaurants gastronomiques parisiens. In: LEMPS, A. H.; PITTE, $\therefore$ J. R. Les restaurants dans le monde et à travers les àges. $§$ Grenoble: Editions glénat, 1990.

д. CAZELAIS, N. Le tourisme gourmand: la dictature des iे guides? Téoros, v. 25, n. 1, p.15-18, 2006.

$\doteq$ CINOTTO, S. All things italien, italien american consumers, 8 the transnational formation of taste, and commodification of difference. In: CINOTTO, S. (Ed.). Making italian America: \pm consumer culture and production of ethinic identities. New 今 York: Fordham University Press, 2014.

COBB, R. The paradox of authenticity in a globalized world. New York: Palgrave: Macmillan, 2014.

COLLAÇO, J. H. L. Sabores e memórias: cozinha italiana e construção identitária em São Paulo. 2009. 297 f. Tese (Doutorado em Antropologia) - Universidade de São Paulo, São Paulo, 2009.
CORÇÃO, M. A influência do gosto da cozinha portuguesa na história da alimentação no Brasil de Câmara Cascudo. Estudos Históricos, v. 25, n. 50, p. 408-425, 2012.

COURTINE, R. Balzac à table. Paris: Laffont, 1976.

COUTO, C. Arte de cozinha: alimentação e dietética em Portugal e no Brasil (séculos XVII-XIX). São Paulo: Senac, 2007.

CRANE, D. Ensaios em arte, moda e globalização cultural. Organização de Maria Lucia Bueno. São Paulo: Senac, 2012 .

CSERGO, J.; LEMASSON, J. P. (Ed.). Voyages en gastronomie: l'invention des capitales et des régions gourmandes. Paris: Éditions autrement, 2008.

DE JEAN, J. A essência do estilo: como os franceses inventaram a alta-costura, a gastronomia, os cafés chiques, o estilo, a sofisticação e o glamour. Rio de Janeiro: Civilização brasileira, 2010.

DORIA, C. A. A culinária materialista: construção racional do alimento e do prazer gastronômico. São Paulo: Senac, 2009 .

Atala e o DOM que surpreende: como um ex-punk virou chef proprietário do mais badalado restaurante de S.P. Tropico, [20--]. Disponível em: www.revistatropico. com.br/tropico/html/1118,1.shl. Acesso em: 12 jul. 2012.

DROUARD, A. Histoire des cuisiniers en France: XIX-XX siècle. Paris: CNRS éditions, 2007.

Le mythe gastronomique français. Paris: CNRS editions, 2010.

DUCASSE, A. Prefácio. In: ATALA, A. D.O.M. Redescobrindo ingredientes brasileiros. São Paulo: Melhoramentos, 2013. 292p

; LHERITIER, J. Préface. In: PETRINI, C. Bon, propre et juste: éthique de la gastronomie et souverainete alimentaire. Paris: Edition Yves Michel, 2006.

DUMAS, A. Propos d'art et de cuisine. Paris: Calmann Lévy, 1877.

ECHEVERRIA, O.; MORENA DE BRITO, A. Quelle geographie gourmande à São Paulo? Localisation et logiques de localisations des restaurants "étoiles". In: MARCILHAC, V.; MORINAUX, V. (Ed.). Les établissements de restauration dans le monde. Paris: Harmattan, 2012. (Geographie cultures).

ESCOFFIER, A. Souvenirs inédits: 75 ans au service de l'art culinaire. Marseille: Éditions Jeanne Lafitte, 1985.

A guide to modern cookery. London: Studio editions, 1994.

FEATHERSTONE, M. Cultura de consumo e pósmodernismo. São Paulo: Studio Nobel, 1995.

O desmanche da cultura: globalizacão, pósmodernismo e identidade. São Paulo: Studio Nobel, 1995.

FERGUSON, P. P. A cultural field in the making: gastronomy in $19^{\text {th }}$ Century France. American Journal of Sociology, v. 104, n. 3, p. 597-641, 1998.

Accounting for taste: the triumph of french cuisine. Chicago: The University of Chicago Press, 2004.

Michelin débarque à New York: la loi des guides? In: CSERGO, J.; LEMASSON, J. P. (Org.). Voyages en gastronomie: l'invention des capitales et des régions gourmandes. Paris: Éditions autrement, 2008. p. 116-126.

FLANDRIN, J. L.; MONTANARI, M. (Ed.). Histoire de la alimentation. Paris: Fayard, 1997.

FOOD Omnivore Book, n. 5, 2016

GIDDENS, A. As consequências da modernidade. São Paulo: Unesp, 1991. 
A vida em uma sociedade pós-tradicional. In: GIDDENS et al. Modernização reflexiva: política, tradição e estética na ordem social moderna. São Paulo: Unesp, 1997.

. Modernidade e identidade. Rio de Janeiro: Zahar, 2002.

GOODY, J. Cooking, cuisine and class a study in comparative sociology. Cambridge: Cambridge University Press, 1982.

GRIMOD DE LA REYNIÈRE, A. B. Journal des gourmands et des belles, ou l'épicurien français. Paris: Capelle et renaud, 1806 .

Manuel des amphytrions: contenant un traité de la dissection des viandes à table: nomenclature des menus les plus nouveaux pour chaque saison, et des éléments de politesse gourmande. Paris: Editions A. M. métaillié, 1984

HEINICH, N. Du peintre a l'artiste: artisans et académiciens a l'age classique. Paris: Minuit, 1993.

HOBSBAWM, E. A invenção das tradições. In: HOBSBAWN, E.; RANGER, T. (Org.). A invenção das tradições. Rio de Janeiro: Paz e Terra, 1984.

HUETZ DE LEMPS, A.; PITTE, J. R. Les restaurants dans le monde et à travers les àges. Grenoble: Éditions glénat, 1990.

JAMES, K. Escoffier: o rei dos chefs. São Paulo: Senac, 2008.

KARPIC, L. Le guide rouge Michelin. Sociologie du travail, v. 42, p. 369-389, 2000.

KELLY, I. Carême: o cozinheiro dos reis. Rio de Janeiro: Zahar, 2005.

LABRO, C. Le Noma au goût du bush. Le Magazine le monde, n. 236, p. 50-54, mars 2016.

MARCILHAC, V.; MORINAUX, V. (Ed.). Les établissements de restauration dans le monde. Paris: Harmattan, 2012. (Geographie cultures).

MARINETTI, F. T.; FILLİA. A cozinha futurista. Introdução, tradução e notas de Maria Lúcia Mancinelli. São Paulo: Alameda, 2009

MASANO, I. R. A gastronomia paulistana: o local e o global no mesmo prato. 2011. 262 f. Dissertação (Mestrado) Universidade de São Paulo, São Paulo, 2011.

MATTA, R. "L'indien” à table dans les grands restaurants de Lima (Pérou). Anthropology of food, déc. 2010. Disponível em: http://aof.revues.org/6592. Acesso em: 13 jun. 2013.

MESPLÈDE, J. F. Trois étoiles au guide Michelin: une histoire de la haute gastronomie française. Paris: Édition gründ, 1998.

ORTIZ, R. Mundialização e cultura. São Paulo: Brasiliense, 1994.

Anotações sobre o universal e a diversidade.

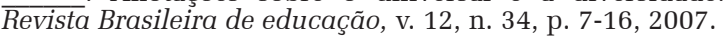

ORY, Pascal. Le discours gastronomiques français de nos origines à nos jours. Paris: Gallimard: Julliard, 1998.

PETRINI, C. Bon, propre et juste: éthique de la gastronomie et souverainete alimentaire. Prefácio de Jean Lheritier e Alain Ducasse. Paris: Édition Yves Michel, 2006.

Gastronomia, direito humano. Antropologia ago. 2006. Disponível em: http://agreste.blogspot.com. br/2006/08/gastronomia-direito-humano.html. Acesso em 1 dez. 2013 .

POULAIN, J. P. Sociologia da alimentação. Florianópolis: UFSC, 2004.

; NEIRINCK, E. Histoire de la cuisine et des cuisiniers: techniques culinaires et pratiques de table, en France, du Moyen-Âge à nos jours. Paris: Delagrave éditions, 2004

RAMBOURG, P. Histoire de la cuisine et la gastronomie françaises. Sain-Amand-Montrond: Perrin, 2010.

RAO, H.; MONIN, P.; DURAND, R. Institutional change in Toque Ville: nouvelle cuisine as an identity movement in french gastronomy. American journal of Sociology, v. 108, n. 4, p. 795-843, 2003.

Border crossing: bricolage and the erosion of categorical bounderies in french gastronomy. American Sociological Review, v. 70, p. 968-991, 2005.

SEIGEL, J. Paris boêmia: cultura, política e os limites da vida burguesa. Porto Alegre: L\&PM, 1992.

SOBRAL, J. M. The high and low in the making of a portuguese national cuisine in the nineteenth and twentieth centuries. In: KLEIN, J. A.; MURCOTT, A. (Ed.) Food consumption in global perspective. Basingstoke: Palgrave Mcmillan, 2014.

STENGEL, K. Chronologie de la gastronomie et de l'alimentation. Nantes: Éditions du temps, 2008.

SVEJENOVA, S.; MAZZA, C.; PLANELLAS, M. Cooking up change in Haute Cuisine: Ferran Adrià as an institutional entrepreneur. Journal of organizational behavior, v. 28, p. 539-561, 2007.

SUAUDEAU, L. Cartas a um jovem chefe: caminhos no mundo da cozinha. 3. ed. Rio de Janeiro: Elsevier, 2007.

SUE, E. Les septs péches capitaux: la gourmandise. Geneve: Slatkine, 1992.

SPANG, R. L. A invenção do restaurante: Paris e a moderna cultura gastronômica. Rio de Janeiro: Record, 2003.

TERRRANCE, I. Le monde de la grande restauration en France: la reussité est-elle dans l'assiette? Paris: L'Harmattan, 1996. (Logiques sociales).

THIS, H. La cuisine note à note en douze questions sourriantes. Paris: Belin, 2012.

WILLIAMS, R. Base e superestrutura na teoria cultural marxista. Revista USP, n. 66, p. 210-225, jul./ag. 2005,

Quando foi o modernismo? Revista Margem Esquerda: ensaios marxistas, n. 6, p. 177-182, set., 2005.

WU, D. Y. H. Cultural nostalgia and global imagination: japanese cuisine in Taiwan. In: OK KIM, K. (Ed.). Reorientating cuisine: east-asian foodways in the twenty-first century. New York: Berghahn, 2015.

YAN, N. Un-defining authenticity in chinese restaurants and cuisine. In: LYSAGHL, P. (Ed.). Time for food: everyday food and changing meal habits in a global perspective. Turku: Abo Akademi University Press, 2012.

\section{GUIAS GASTRONÔMICOS}

Guide Gaut et Millau (1971-2016).

Guide Michelin São Paulo e Rio de Janeiro (2015).

Guia 4 Rodas Brasil (1964-2015).

Guide Rouge Michelin France (1987-2016).

Guide Rouge Michelin Paris (1980-2016).

Restaurant Week, 50 World's Best (2002-2015). 


\section{FROM FRENCH GASTRONOMY TO GLOBAL GASTRONOMY: hybridism and invented identities}

\author{
Maria Lúcia Bueno
}

The objective of this reflection is to comprehend the transformation of the dynamic of the process of internationalization of the globalization using as a theme the gastronomy. This theme is thought as a cultural field (Bourdieu) and using as clippings the chefs, the restaurants and the gastronomic guides analyzed under the sociohistorical perspective. Considering the balance between the penetration of the gastronomic culture in contexts more apart from each other, besides being diverse among themselves, the proposal of this article is to discuss how the consolidation of a gastronomic global market is in contrast with the continuous exercises of affirming the localities and the particular identities.

KEYWORDS: gastronomic field and globalization, chefs and restaurants, French gastronomy and Brazilian gastronomy, invented identities.

\section{DE LA GASTRONOMIE FRANÇAISE A LA GASTRONOMIE MONDIALE: hybridités et identités inventées}

Maria Lúcia Bueno

L'objectif de cette réflexion est de comprendre la transformation de la dynamique du processus de mondialisation dans un monde globalisé. Le thème choisi est la gastronomie, considérée comme un champ culturel (Bourdieu). On fait des recoupements entre les chefs cuisiniers, les restaurants et les guides gastronomiques, le tout étant analysé dans une perspective socio-historique. Compte tenu de l'équilibre établi entre la pénétration de la culture gastronomique dans des domaines les plus éloignés les uns des autres, sans compter leur diversité, cet article se propose de discuter comment la consolidation d'un marché mondial de la gastronomie a pour contre partie des exercices continus d'affirmation de localités et d’identités spécifiques.

Mots-clés: champ gastronomique et mondialisation, chefs et restaurants, gastronomie française et gastronomie brésilienne, identités inventées.

Maria Lúcia Bueno - Doutora em Ciências Sociais. Pós-doutorados: Instituto de Artes da Unicamp/ FAPESP (1996-99); École des Hautes Études em Science Sociales/EHESS; Université Paris Est/FAPESP; Institut d'études éuropéennes, Université, Paris 8/CAPES; New School for Social Research, NY/CAPES. Professora adjunta do Instituto de Artes e Design da Universidade Federal de Juiz de Fora/UFJF-MG; Professora dos Programas de Pós-Graduação em Artes, Cultura e Linguagens(PPG-ACL/UFJF) e Ciências Sociais (PPGCSO/UFJF). Líder do grupo de pesquisa CNPQ Cultura e Artes Visuais. Coordenadora do GT de Sociologia da Arte (SBS). Tem experiência nas áreas de sociologia da cultura e da arte e de Historia social da cultura e da arte, com ênfase nos seguintes temas: Artistas, Instituições e Mercado;Cultura e Arte Brasileira;Arte Moderna e Contemporânea; Trabalho artístico e cultural: Consumo e estilos de Vida; Gastronomia; Moda; Cultura Urbana; Indústria Cultural; Modernidade; Mundialização e Globalização. Publicações recentes: Cultura Visual e estilos de vida. As revistas de moda francesas e as estratégias de marketing da alta costura no início do século XX. Maracanan, v. 12, p. 75-96, 2016; Arte, mundo, uma vígula. NAVA, v. 1, p. 195-200, 2016; Une modernité brésilienne: art moderne et marché de l'art à São Paulo et Rio de Janeiro au milieu du XX siècle. Sociologie de l'Art, v. OPuS 22, p. 113-137, 2014. 